\title{
Purification and Characterization of Phenylalanine Ammonia Lyase from Trichosporon cutaneum
}

\author{
Andrea Goldson-Barnaby ${ }^{1,2}$ and Christine H. Scaman ${ }^{1}$ \\ ${ }^{1}$ Food, Nutrition, and Health, University of British Columbia, 2205 East Mall, Vancouver, BC, Canada V6T $1 Z 4$ \\ ${ }^{2}$ Department of Chemistry, University of the West Indies, Kingston, Jamaica
}

Correspondence should be addressed to Christine H. Scaman; christine.scaman@ubc.ca

Received 25 June 2013; Accepted 13 August 2013

Academic Editor: Qi-Zhuang Ye

Copyright @ 2013 A. Goldson-Barnaby and C. H. Scaman. This is an open access article distributed under the Creative Commons Attribution License, which permits unrestricted use, distribution, and reproduction in any medium, provided the original work is properly cited.

\begin{abstract}
Trichosporon cutaneum phenylalanine ammonia lyase was selected as a model to investigate the dual substrate activity of this family of enzymes. Sequencing of the PAL gene identified an extensive intron region at the N-terminus. Five amino acid residues differing from a prior report were identified. Highest Phe: Tyr activities $(1.6 \pm 0.3: 0.4 \pm 0.1 \mu \mathrm{mol} / \mathrm{h}$ g wet weight $)$ were induced by Tyr. The enzyme has a temperature optimum of $32^{\circ} \mathrm{C}$ and a $\mathrm{pH}$ optimum of 8-8.5 and shows no metal cofactor dependence. MichaelisMenten kinetics (Phe, $K_{m} 5.0 \pm 1.1 \mathrm{mM}$ ) and positive allostery (Tyr, $K^{\prime} 2.4 \pm 0.6 \mathrm{mM}$, Hill coefficient $\left.1.9 \pm 0.5\right)$ were observed. Anion exchange chromatography gave a purification fold of 50 with $20 \%$ yield. The His-Gln motif (substrate selectivity switch region) indicates the enzyme's ability to act on both substrates.
\end{abstract}

\section{Introduction}

Phenylalanine ammonia lyase (PAL, EC 4.3.1.24) catalyzes the conversion of phenylalanine to trans-cinnamic acid, as a step in the phenylpropanoid pathway of plants and in the formation of secondary products of metabolism in some microorganisms $[1,2]$. In some instances, the enzyme also converts tyrosine to para-hydroxycinnamic acid. These dual substrate enzymes are classified as phenylalanine/tyrosine ammonia lyases, (EC 4.3.1.25). Enzymes with a greater catalytic efficiency for tyrosine are known as tyrosine ammonia lyase (TAL, EC 4.3.1.23). There are no known genes that code for a lyase that has activity exclusively with tyrosine.

Interest in PAL is from two perspectives. First, the structural features of the enzyme responsible for its substrate specificity have not been fully elucidated. Second, a more selective and efficient TAL is of interest for industrial applications. The specificity of PAL for phenylalanine relative to tyrosine varies by over $10^{6}$ between biological sources, and typically, the efficiency of Phe turnover is higher than Tyr $[3,4]$. An understanding of the basis for this astounding range of substrate preference is required to rationally engineer an efficient tyrosine-specific enzyme for use in the synthesis of $p$-hydroxycinnamic acid for industrial applications [5]. The microbial production of aromatic chemicals continues to increase as it allows for the use of greener technologies and renewable energy sources [6].

PAL has been extensively characterized from a wide variety of plant sources [7], but only a few microbial sources of the enzyme have been investigated $[8,9]$. PAL from the yeast Trichosporon cutaneum (TcPAL), identified as an enzyme able to metabolize both Phe and Tyr and possessing a relatively high level of activity with tyrosine, was selected as a model to further investigate the dual substrate activity of this family of enzymes. Several novel findings were noted and are reported herein. The cloned gene was found to have a single intron region near the N-terminus of the enzyme and five amino acid residues that differed from a previous report [6]. A His-Gln motif was identified which appears to be a characteristic feature of PAL enzymes displaying dual substrate activity with tyrosine and phenylalanine. This is the first reported characterization of the TcPAL enzyme with regard to its temperature and $\mathrm{pH}$ optimum as well as metal dependence. 


\section{Materials and Methods}

2.1. Cloning of the TcPAL Gene. Escherichia coli bacterial strains were cultured in Luria Bertani (LB, Mediatech, Herndon, VA) liquid medium. Kanamycin $(50 \mu \mathrm{g} / \mathrm{mL})$ was added to LB media and plates when growing bacteria containing plasmids.

The yeast strain Trichosporon cutaneum (ATCC 58094) was purchased from the American Type Culture Collection (Manassass, VA). Shake cultures were grown aerobically in Dagley's medium at $30^{\circ} \mathrm{C}$ at $100 \mathrm{rpm}$ with addition of tyrosine $(2.0 \mathrm{mM})$ at $30^{\circ} \mathrm{C}$ to an OD600 of 3. Cells were pelleted by centrifugation $\left(9000 \mathrm{xg}, 15 \mathrm{~min}, 4^{\circ} \mathrm{C}\right)$. Genomic DNA was extracted utilizing a Qiagen DNA purification kit and utilized as template for PCR amplification.

Primer sequences were designed based on the DNA sequence of the T. cutaneum PAL protein. The PAL gene was PCR amplified using Phusion DNA polymerase (New England Biolabs) from T. cutaneum genomic DNA with the $5^{\prime}$ primer TcPAL- F: $5^{\prime}$-CGCGAATTCATGTTTATTG AGACC $-3^{\prime}$ as the forward primer (EcoRI site underlined) and $3^{\prime}$ primer TcPAL- R: $5^{\prime}$-GAAGCTTTTAGAACATCTTGCCAAC- $3^{\prime}$ as the reverse primer (HindIII site underlined). Control reactions were also performed. The amplified PCR fragment was purified, digested with HindIII and EcoRI, and inserted in the pET30a vector to give plasmid pET-30a (+) TcPAL. E. coli DH5 $\alpha$ competent cells were transformed with the plasmid construct by use of heat shock treatment. Positive clones were identified by restriction analysis, and plasmid DNA was submitted for DNA sequencing.

Database comparison was performed with the BLAST search tools on the server of the National Center for Biotechnology Information, National Library of Medicine, NIH (http://www.ncbi.nlm.nih.gov/). Multiple sequence alignments were performed using ClustalW. Intron analysis was performed using GENSCAN.

2.2. Cell Culture and Extraction. Shake cultures of T. cutaneum were grown aerobically in Dagley's medium at $30^{\circ} \mathrm{C}$ at $100 \mathrm{rpm}$ with addition of tyrosine $(2.0 \mathrm{mM})$ at $30^{\circ} \mathrm{C}$ to an OD600 of 3. Cells were harvested by centrifugation at $23,500 \mathrm{xg}$ for $15 \mathrm{~min}$ at $4^{\circ} \mathrm{C}$. The cell pellet was resuspended in extraction buffer (50 mM Tris- $\mathrm{HCl}, \mathrm{pH} 8.0,1 \mathrm{mM}$ EDTA, $10 \mathrm{mM}$ 2-mercaptoethanol, protease inhibitor cocktail tablets EDTA free, and 1 tablet per $100 \mathrm{~mL}$ ) in a $1: 4$ ratio (wet weight:buffer), and the cells were disrupted by vortexing with glass beads for $6 \mathrm{~min}$ with intermittent cooling on ice. After centrifugation, aliquots of supernatant were desalted using a PD-10 column (GE Healthcare) and used for enzyme purification. Protein concentration was determined by the Bradford assay [10].

2.3. Enzyme Assays. The PAL/TAL activity of enzyme extracts was measured using a spectrophotometric assay [11]. For preliminary induction studies, the enzyme activity was determined using an end point assay using Phe $(40 \mathrm{mM})$ or Tyr $(2 \mathrm{mM})$ in $10 \mathrm{mM}$ Tris- $\mathrm{HCl}(\mathrm{pH} 8.5)$ at a temperature of $37^{\circ} \mathrm{C}$ for $15 \mathrm{~min}$. The reaction was terminated by the addition of $25 \%$ trichloroacetic acid $(200 \mu \mathrm{L})$. Samples were centrifuged at $13,000 \mathrm{xg}$ for $15 \mathrm{~min}$, and the absorbance was measured. All other experiments were conducted utilizing a continuous spectrophotometric assay at a temperature of $30^{\circ} \mathrm{C}$ for $2 \mathrm{~min}$. Assays were initiated by addition of enzyme extract $(200 \mu \mathrm{L})$ to substrate solution $(800 \mu \mathrm{L})$ preequilibrated at $30^{\circ} \mathrm{C}$. For kinetic analysis, solutions containing Phe $(0.5 \mathrm{mM}$ to $100 \mathrm{mM})$ or $\operatorname{Tyr}(0.5 \mathrm{mM}$ to $10 \mathrm{mM})$ in $10 \mathrm{mM}$ Tris- $\mathrm{HCl}(\mathrm{pH} 8.0)$ were utilized. The same enzyme extract was used to compare the kinetic constants for PAL and TAL activities. The absorbance of trans-cinnamic acid was measured at $290 \mathrm{~nm}$, whereas para-hydroxycinnamic acid was measured at $315 \mathrm{~nm}$. Kinetic data was analyzed using GraphPad Statistical Software (Version 5, California) which combines biostatistics, curve fitting (nonlinear regression), and scientific graphing into a comprehensive program.

2.4. PAL Purification and Characterization. All purification steps were carried out at $4^{\circ} \mathrm{C}$. Crude cell free extract of $T$. cutaneum from PD-10 columns was applied to a Fast Protein Liquid Chromatography anion exchange HiTrap Q Sepharose column $(2.5 \times 1.0 \mathrm{~cm})$ pre-equilibrated with Tris- $\mathrm{HCl}$ buffer (0.1 M, pH 8.0). The adsorbed enzyme was eluted with a linear gradient of $\mathrm{KCl}$ from 0 to $0.3 \mathrm{M}$ in the same buffer [12]. Fractions with PAL activity were pooled and exchanged with extraction buffer using Millipore centrifugal filter units with a $30 \mathrm{kDa}$ molecular cutoff.

The temperature optimum of the enzyme was determined by performing enzyme assays at $28^{\circ} \mathrm{C}, 32^{\circ} \mathrm{C}, 36^{\circ} \mathrm{C}$, and $40^{\circ} \mathrm{C}$ with Tris- $\mathrm{HCl}(50 \mathrm{mM}, \mathrm{pH} 8.0)$ as buffer. The $\mathrm{pH}$ optimum was determined by conducting enzyme assays at $32^{\circ} \mathrm{C}$ with Tris- $\mathrm{HCl}(50 \mathrm{mM})$ adjusted to 7.3, 7.6, 8.2, 8.6, and 8.9. Metal dependence studies were performed using the chloride salts of sodium, potassium, magnesium, and ferrous at a total salt concentration of $100 \mathrm{mM}$ in Tris- $\mathrm{HCl}$ buffer (50 mM, pH 8.0).

\section{Results and Discussion}

3.1. Sequencing of the PAL Gene. The PAL gene from T. cutaneum was amplified from genomic DNA using PCR. A $2114 \mathrm{bp}$ fragment size was generated, cloned into the pET30a vector, and submitted for sequence analysis. The gene sequence showed high similarity with other PAL enzymes in the NCBI database. Protein blast analysis revealed that the PAL shares identity with the yeast PALs Trichosporon asahii (70\%), Rhodosporidium toruloides (50\%), Rhodotorula mucilaginosa (49\%), and Rhodotorula glutinis (48\%).

Sequencing of the TcPAL gene from two independent clones revealed five amino acid residues that differ from the sequence previously reported by Breinig et al. [6], namely, Gln 74, Ala 274, Val 298, Pro 322, and Lys 486. A comparison of our TcPAL sequence with the closely related Trichosporon ashaii PAL revealed that the residues at positions 74, 274, and 486 were identical (Table 1). However, the residue equivalent to 298 matched the Ala residue previously reported rather than the Val in our sequence. There was no obvious consensus for the amino acid residue corresponding to Pro 322 for the three proteins. Analysis of the T. cutaneum gene 
TABLE 1: Amino acids reported for Trichosporon cutaneum PAL and equivalent residues identified in T. ashaii $\mathrm{P} / \mathrm{TAL}^{\mathrm{a}}$.

\begin{tabular}{lccccc}
\hline P/TAL source & \multicolumn{5}{c}{ Residue $^{\mathrm{b}}$} \\
\hline T. cutaneum (current work) & Q74 & A274 & V298 & P322 & K486 \\
T. cutaneum (ABA69898.1) & R74 & V274 & A298 & S322 & R486 \\
T. ashaii (EKD03338.1) & Q129 & A327 & A351 & E375 & K539 \\
\hline
\end{tabular}

${ }^{\mathrm{a}}$ Genbank number in brackets.

${ }^{b}$ Blue: polar uncharged residues; red: positively charged; green: negatively charged; black: polar; purple: proline.

sequence by GENESCAN utilizing the parameter matrices for Arabidopsis and maize predicted the presence of an intron within the TcPAL gene sequence at position 121 through 1182 (1062 bp), which was confirmed with the translated protein sequence.

In the substrate selectivity switch region of PAL:TAL enzymes a His-Leu motif is characteristic of TALs, whereas Phe-Leu is characteristic of PALs [3]. In TcPAL, His-Leu was replaced by His-Gln. This motif was also observed in other microbial PAL enzymes (Figure 1). Other P/TAL enzymes with the His-Gln motif possess dual substrate activity to Phe and Tyr, with a $K_{m \mathrm{Phe} / \mathrm{Tyr}}$ ratio greater than one. Examples include T. cutaneum with ratios of 3.2 or 8.2 (current work, [13]), R. toruloides, ratio 1.6 [14], R. glutinis, ratio 2.3 and 1.9 $[9,15], R$. mucilaginosa, ratio 2.0 [13], and R. graminis, ratio 2.9 [13]. Activity with Tyr has not been previously reported for T. asahii, but based on this motif, it is predicted to possess both PAL and TAL activities. In addition to the His-Gln selectivity switch region observed in the protein sequence of these enzymes, other residues surrounding this motif were conserved, specifically, Glu His Gln Leu Cys. Residues forming the hydrophobic substrate binding pocket described by Watts et al. [3] were also conserved (Leu 194, Leu 242, and Val 245).

3.2. PAL Purification and Characterization. PAL purification usually requires multiple steps to obtain a homogenous preparation [16]. Due to the enzyme's relative instability, a rapid purification procedure is desirable. Purification of TcPAL by acid precipitation, aqueous two-phase partitioning, and anion exchange chromatography was investigated (Table 2). TcPAL was obtained with an approximate yield of $20 \%$ and 50 -fold purification from the HiTrap Q Sepharose column (Figure 2). SDS PAGE of the eluted protein revealed the presence of the desired band at $79 \mathrm{kDa}$, confirmed by Western blot (not shown) and two other unidentified bands at $67 \mathrm{kDa}$ and $31 \mathrm{kDa}$. PAL is typically tetrameric with four identical monomers ranging from 77 to $83 \mathrm{kDa}$ [17]. This twostep procedure is rapid and efficient in comparison to the four-step procedure reported by Vannelli et al. [13] which produced a purification fold of 14 and an overall yield of $6 \%$. Vannelli et al. [13] used a quaternized polyethyleneimine anion exchange column, resulting in a 4 -fold purification. The theoretical pI of TcPAL reported by Vannelli et al. [13] was 6.3 , while the pI of the enzyme as determined from isoelectric focusing analyses was 5.8. TcPAL from the present study has

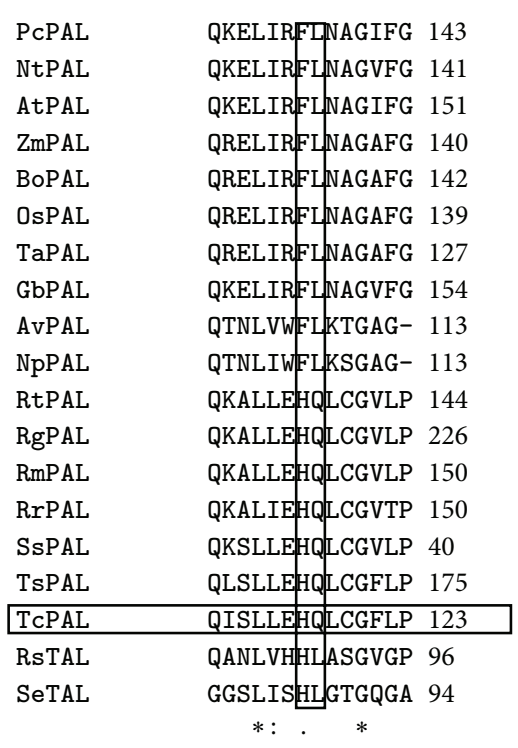

FIGURE 1: Substrate selectivity switch region (residues in bold) identified in PAL and TAL enzymes. FL is indicative of PALs, HQ for PAL/TALs, and HL for TAL enzymes. Abbreviations with Uniprot or Genbank number: Pc: Petroselinum crispum (P45729), Nt: Nicotiana tabacum (P25872), At: Arabidopsis thaliana (P35510), Bo: Bambusa oldhamii (C0LL35), Zm: Zea mays (B6SWA0), Os: Oryza sativa (A2X7F7), Ta: Triticum aestivum (Q43210), Gb: Ginkgo biloba (A7UHB6), Av: Anabaena variabilis (Q3M5Z3), Np: Nostoc punctiforme (B2J528), Rt: Rhodosporidium toruloides (P11544), Rg: Rhodotorula glutinis (G0SVG1), Rm: Rhodotorula mucilaginosa (P10248), Rr: Rhodotorula graminis (CAD23828.1), Ss: Sporidiobolus salmonicolor (E0YNE2), Ts: Trichosporon asahii (EKD03338.1), Tc: Trichosporon cutaneum (ABA69898.1), Rs: Rhodobacter sphaeroides (Q3IWB0), and Se: Saccharothrix espanaensis (Q2EYY5).

a theoretical pI of 6.2 because of the sequence differences we obtained, which may account for the difference observed in the behaviour of the enzyme during anion exchange chromatography. The enzyme has a $\mathrm{pH}$ optimum in the range of 8.0-8.5 (Figure 3) and a temperature optimum of $32^{\circ} \mathrm{C}$ (Figure 4) and shows no metal dependence on the chloride salts of sodium, potassium, magnesium, and ferrous.

TcPAL exhibited the highest activity with Phe : Tyr $(1.6 \pm$ $0.3: 0.4 \pm 0.1 \mu \mathrm{mol} / \mathrm{h}$ g wet weight) when induced by tyrosine $(2 \mathrm{mM})$. Control and phenylalanine $(2 \mathrm{mM})$ induced cultures possessed lower activities (Phe: Tyr $0.9 \pm 0.03: 0.2 \pm 0.1$ and $0.4 \pm 0.2: 0.3 \pm 0.1 \mu \mathrm{mol} / \mathrm{h}$ g wet weight, resp.), while no activity was found when $2 \mathrm{mM}$ glucose was in the growth media, consistent with previous reports [17].

Purified TcPAL displayed typical Michaelis-Menten kinetics with Phe but atypical Michaelis-Menten kinetics were the best fit with Tyr (Figure 5). Vannelli et al. [13] also reported typical Michaelis Menten kinetics with Phe $\left(K_{m}\right.$ $4.9 \pm 0.9 \mathrm{mM})$ and positive allostery with $\operatorname{Tyr}\left(K^{\prime} 0.6 \mathrm{mM}\right.$, Hill coefficient $2.6 \pm 0.4$ ) comparable to the findings of this present study. Interestingly, the yeast PALs from $R$. toruloides, R. glutinis, and R. mucilaginosa with high protein sequence identity to TcPAL appear to follow MichaelisMenten kinetics with both substrates. Positive allostery may 
TABLE 2: Purification of the PAL enzyme from Trichosporon cutaneum ${ }^{\mathrm{a}}$.

\begin{tabular}{|c|c|c|c|c|c|}
\hline Method & Total activity ${ }^{\mathrm{b}}(\mathrm{U})$ & Total protein (mg) & Specific activity (U/mg) & Purification fold & Yield (\%) \\
\hline \multicolumn{6}{|l|}{ Anion exchange } \\
\hline Crude & $0.05 \pm 0.01$ & $0.38 \pm 0.09$ & $0.15 \pm 0.00$ & - & 100 \\
\hline Post & $0.01 \pm 0.00$ & $0.001 \pm 0.00$ & $7.39 \pm 0.73$ & 49.6 & 20 \\
\hline \multicolumn{6}{|l|}{ Acid precipitation } \\
\hline Crude & $0.16 \pm 0.03$ & $1.04 \pm 0.74$ & $0.20 \pm 0.10$ & - & 100 \\
\hline Post & $0.15 \pm 0.04$ & $0.61 \pm 0.28$ & $0.26 \pm 0.06$ & 1.3 & 94 \\
\hline \multicolumn{6}{|l|}{ Aqueous two-phase ${ }^{c}$} \\
\hline Crude & $0.07 \pm 0.03$ & $0.39 \pm 0.14$ & $0.21 \pm 0.05$ & - & 100 \\
\hline $\mathrm{PEG} / \mathrm{Na}_{2} \mathrm{SO}_{4}$ & $0.02 \pm 0.00$ & $0.08 \pm 0.00$ & $0.33 \pm 0.03$ & 1.5 & 28 \\
\hline $\mathrm{PEG} /\left(\mathrm{NH}_{4}\right)_{2} \mathrm{SO}_{4}$ & $0.02 \pm 0.00$ & $0.10 \pm 0.08$ & $0.10 \pm 0.04$ & 0.5 & 28 \\
\hline PEG/ $\mathrm{Na}_{2} \mathrm{CO}_{3}$ & $0.01 \pm 0.00$ & $0.31 \pm 0.04$ & $0.02 \pm 0.01$ & 0.1 & 14 \\
\hline
\end{tabular}

${ }^{\mathrm{a}}$ Results are the average \pm range of two independent trials. Crude samples are cell culture extracts obtained from a PD- 10 column. ${ }^{\mathrm{b}} 1 \mathrm{U}$ of activity $=1 \mu \mathrm{moL}$ of released tran-cinnamic acid per min. ${ }^{c}$ For aqueous two-phase partitioning, the same crude enzyme extraction was used for each of the PEG/salt systems.

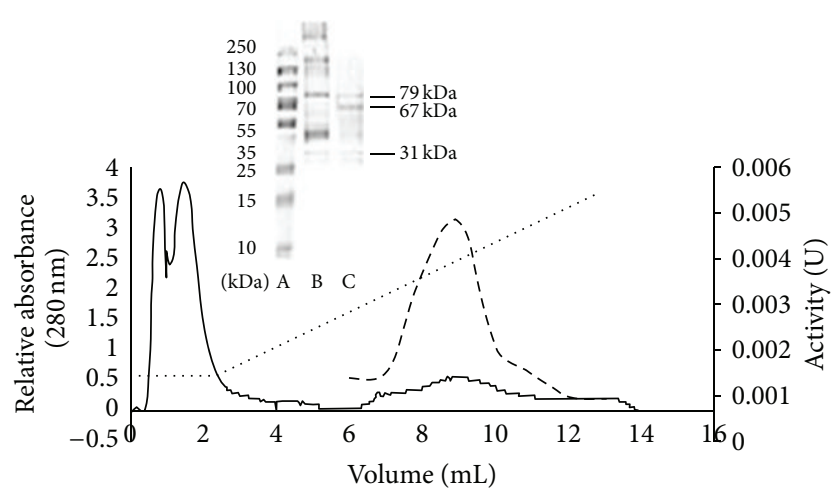

$1 \mathrm{U}$ of activity $=1 \mu \mathrm{moL}$ of released trans-cinnamic acid per minute

$$
\begin{array}{ll}
\text {...... KCI elution gradient }(0 \text { to } 0.3 \mathrm{M}) \\
\text { - } \text { Relative absorbance } \\
\text {--- Activity }
\end{array}
$$

FIGURE 2: Chromatographic profile illustrating the purification of the PAL enzyme from Trichosporon cutaneum extract by anion exchange chromatography. Insert: SDS PAGE of Trichosporon cutaneum PAL enzyme. Lane A, protein ladder; B, crude extract; C, purified protein from anion exchange chromatography. T. cutaneum $\mathrm{PAL}$ at $79 \mathrm{kDa}$.

be a characteristic feature of the Trichosporon species, and it is possible that Trichosporon asahii PAL may share similar enzyme kinetic characteristics to that of TcPAL.

Vannelli et al. [13] reported a PAL/TAL ratio $\left(\left(V_{\max } / K_{m}\right)_{\text {Phe }} /\left(V_{\max } / K^{\prime}\right)_{\text {Tyr }}\right)$ of 0.8 , while we observed a ratio of 2.2 (Table 3). This implies that the enzyme is intrinsically a PAL and not a TAL enzyme. The His-Gln motif observed in the substrate selectivity region of the protein sequence further substantiates this claim.

\section{Conclusion}

Five different amino acid residues not previously reported, namely, Gln 74, Ala 274, Val 298, Pro 322, and Lys 486, were identified from translation of the TcPAL gene sequence.

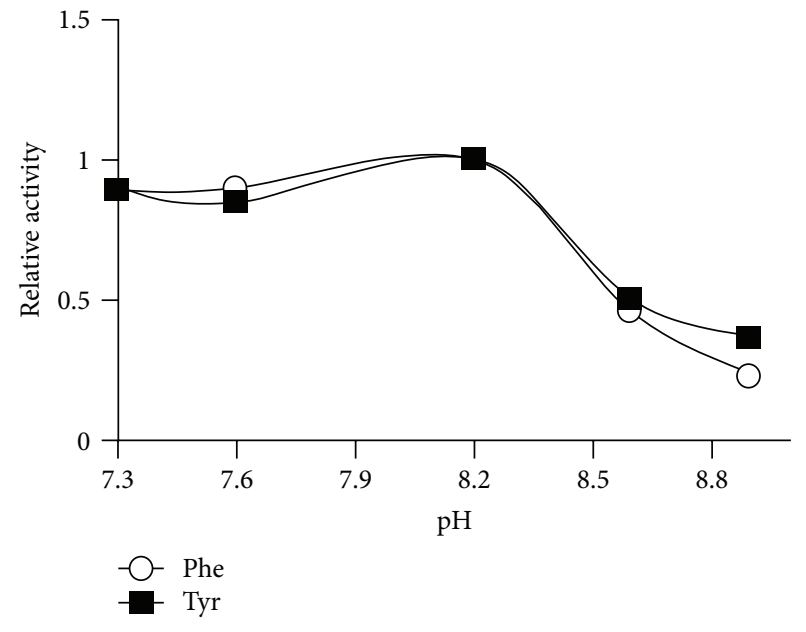

FIgURE 3: $\mathrm{pH}$ dependence studies on the PAL enzyme from the yeast Trichosporon cutaneum. A pH optimum of 8.2 was observed.

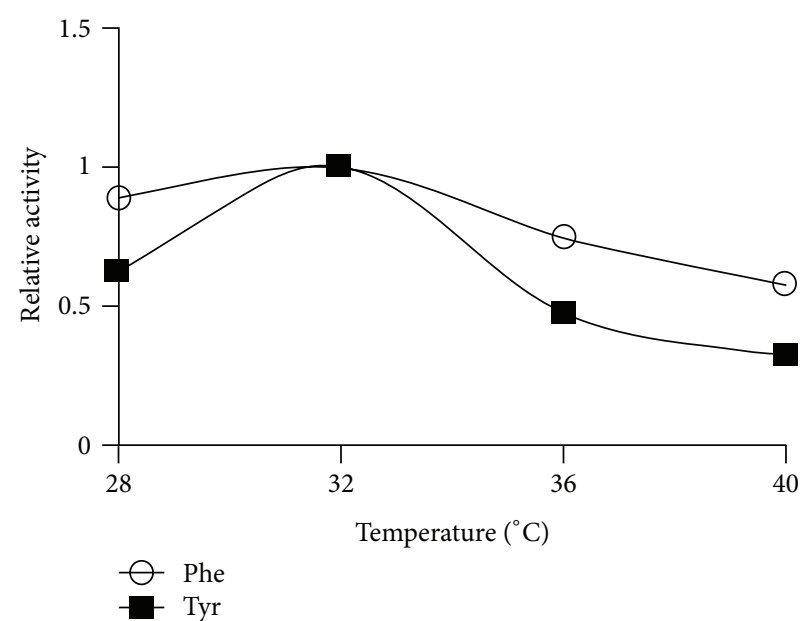

FIgURE 4: Temperature dependence studies on the PAL enzyme from the yeast Trichosporon cutaneum. A temperature optimum of $32^{\circ} \mathrm{C}$ was observed. 
TABLE 3: Kinetic parameters for purified extracts of the PAL enzyme from Trichosporon cutaneum.

\begin{tabular}{|c|c|c|c|c|c|c|c|}
\hline Trial & $\begin{array}{c}\text { Phenylalanine } \\
V_{\max }\left(\mu \mathrm{M} \min ^{-1}\right)\end{array}$ & $\begin{array}{c}\text { Phenylalanine } \\
K_{m}(\mathrm{mM})\end{array}$ & $\begin{array}{c}\text { Phenylalanine } \\
V_{\max } / K_{m}\end{array}$ & $\begin{array}{c}\text { Tyrosine } \\
V_{\max }\left(\mu \mathrm{M} \min ^{-1}\right)\end{array}$ & $\begin{array}{l}\text { Tyrosine } \\
K^{\prime}(\mathrm{mM})\end{array}$ & $\begin{array}{l}\text { Tyrosine } \\
V_{\max } / K^{\prime}\end{array}$ & PAL/TAL ratio \\
\hline 1 & $1.3 \pm 0.1$ & $5.0 \pm 1.1$ & 0.3 & $0.2 \pm 0.02$ & $2.4 \pm 0.6$ & 0.1 & 3.0 \\
\hline 2 & $4.7 \pm 0.6$ & $5.7 \pm 3.0$ & 0.8 & $1.0 \pm 0.1$ & $2.0 \pm 0.4$ & 0.5 & 1.6 \\
\hline 3 & $7.2 \pm 0.8$ & $4.2 \pm 2.0$ & 1.7 & $0.8 \pm 0.1$ & $0.9 \pm 0.4$ & 0.9 & 1.9 \\
\hline
\end{tabular}

For each trial, activity assays for Phe and Tyr were performed on the same enzyme extract. Extracts were obtained from anion exchange chromatography.

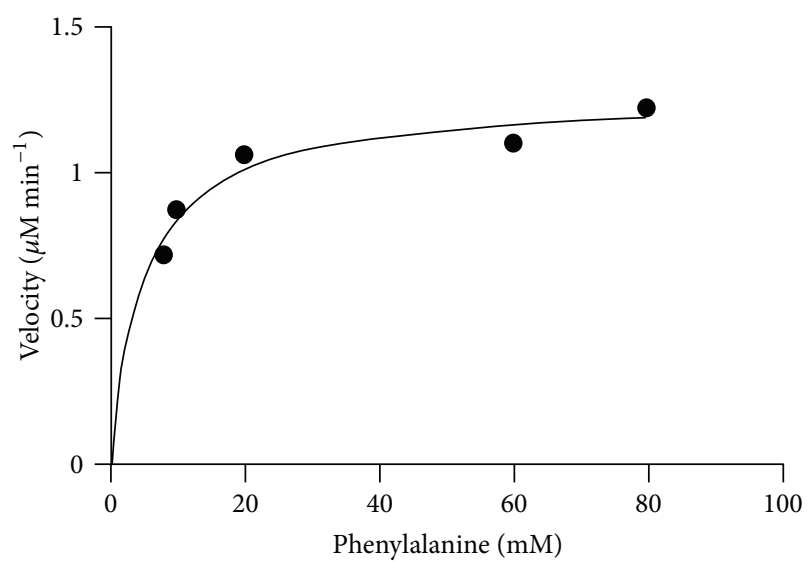

(a)

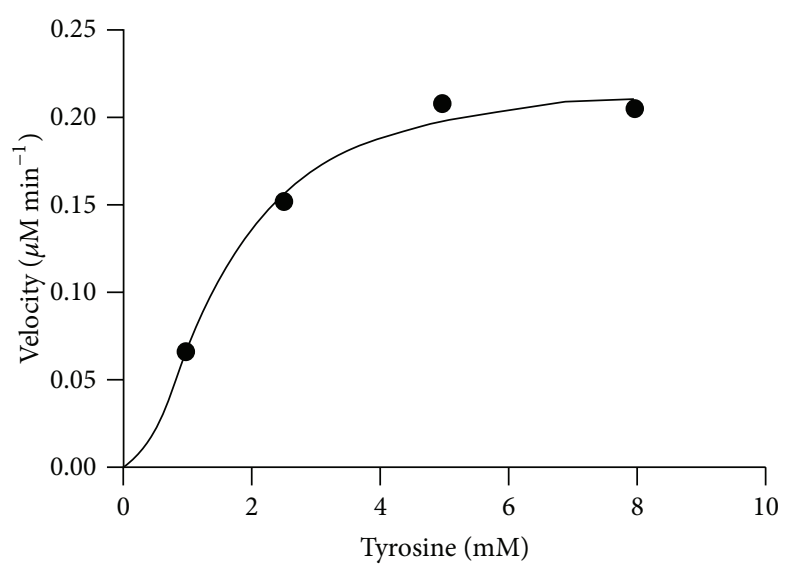

(b)

Figure 5: Purified Trichosporon cutaneum PAL kinetics. (a) Phenylalanine $K_{m} 5.0 \pm 1.1 \mathrm{mM}$, and $R^{2}=0.93$. (b) Tyrosine $K^{\prime}=2.4 \pm 0.6 \mathrm{mM}$, $H=1.9 \pm 0.5, R^{2}=0.99$. Kinetic data was analyzed using GraphPad Statistical Software.

The His-Gln motif identified in the substrate selectivity switch region of TcPAL may potentially be utilized to assist in assigning other uncharacterized microbial ammonia lyases in the genomic database as PAL-specific enzymes possessing activity with tyrosine. TcPAL exhibits greater catalytic efficiency for Phe over Tyr, although the greatest induction of enzyme activity occurred in the presence of Tyr. We confirmed that the enzyme exhibits positive allostery with Tyr, in contrast to Michaelis Menton kinetics with Phe. A twostep purification of the enzyme was achieved by applying a crude cell extract on anion exchange chromatography $(20 \%$ yield, 50 -fold purification).

\section{Acknowledgments}

This work was supported by an NSERC Discovery grant to Christine H. Scaman, and a Canadian Commonwealth Scholarship and Wilson Henderson Fellowship to Andrea Goldson-Barnaby.

\section{References}

[1] K. R. Hanson and E. A. Havir, The Biochemistry of Plants, vol. 7, Academic Press, New York, NY, USA, 1981.

[2] J. S. Williams, M. Thomas, and D. J. Clarke, "The gene stlA encodes a phenylalanine ammonia-lyase that is involved in the production of a stilbene antibiotic in Photorhabdus luminescens TT01," Microbiology, vol. 151, no. 8, pp. 2543-2550, 2005.
[3] K. T. Watts, B. N. Mijts, P. C. Lee, A. J. Manning, and C. SchmidtDannert, "Discovery of a substrate selectivity switch in tyrosine ammonia-lyase, a member of the aromatic amino acid lyase family," Chemistry and Biology, vol. 13, no. 12, pp. 1317-1326, 2006.

[4] M. C. Moffitt, G. V. Louie, M. E. Bowman, J. Pence, J. P. Noel, and B. S. Moore, "Discovery of two cyanobacterial phenylalanine ammonia lyases: kinetic and structural characterization," Biochemistry, vol. 46, no. 4, pp. 1004-1012, 2007.

[5] W. W. Qi, T. Vannelli, S. Breinig et al., "Functional expression of prokaryotic and eukaryotic genes in Escherichia coli for conversion of glucose to p-hydroxystyrene," Metabolic Engineering, vol. 9, no. 3, pp. 268-276, 2007.

[6] S. Breinig, W. W. Qi, F. Sariaslani, T. Vannelli, and Z. Xue, "United States Patent US6951751," 2005.

[7] D. H. Jones, "Phenylalanine ammonia-lyase: regulation of its induction, and its role in plant development," Phytochemistry, vol. 23, no. 7, pp. 1349-1359, 1984.

[8] M. J. MacDonald and G. B. D'Cunha, "A modern view of phenylalanine ammonia lyase," Biochemistry and Cell Biology, vol. 85, no. 3, pp. 273-282, 2007.

[9] Z. Xue, M. McCluskey, K. Cantera, A. Ben-Bassat, F. S. Sariaslani, and L. Huang, "Improved production of $\mathrm{p}$ hydroxycinnamic acid from tyrosine using a novel thermostable phenylalanine/tyrosine ammonia lyase enzyme," Enzyme and Microbial Technology, vol. 42, no. 1, pp. 58-64, 2007.

[10] M. M. Bradford, "A rapid and sensitive method for the quantitation of microgram quantities of protein utilizing the principle of protein dye binding," Analytical Biochemistry, vol. 72, no. 1-2, pp. $248-254,1976$. 
[11] C. W. Abell and R. Shen, "Phenylalanine ammonia-lyase from the yeast rhodotorula glutinis," Methods in Enzymology, vol. 142, no. C, pp. 242-248, 1987.

[12] R. I. Monge, M. Lara, and A. Lopez-Munguia, "Purification and stabilization of phenylalanine ammonia lyase from Sporidiobolus pararoseus," Biotechnology Techniques, vol. 9, no. 6, pp. 423428, 1995.

[13] T. Vannelli, Z. Xue, S. Breinig, W. W. Qi, and F. S. Sariaslani, "Functional expression in Escherichia coli of the tyrosineinducible tyrosine ammonia-lyase enzyme from yeast Trichosporon cutaneum for production of p-hydroxycinnamic acid," Enzyme and Microbial Technology, vol. 41, no. 4, pp. 413422, 2007.

[14] M. Ameyama, E. Shinagawa, K. Matsushita, and O. Adachi, "Growth stimulation of microorganisms by pyrroloquinoline quinone," Agricultural and Biological Chemistry, vol. 48, no. 11, pp. 2909-2911, 1984.

[15] A. A. Gatenby, F. S. Sariaslani, X. Tang, W. W. Qi, and T. Vannelli, “US Patent 6368837," 2002.

[16] R. R. Fritz, D. S. Hodgins, and C. W. Abell, "Phenylalanine ammonia-lyase. Induction and purification from yeast and clearance in mammals," The Journal of Biological Chemistry, vol. 251, no. 15, pp. 4646-4650, 1976.

[17] H. J. Gilbert and M. Tully, "Synthesis and degradation of phenylalanine ammonia-lyase of Rhodosporidium toruloides," Journal of Bacteriology, vol. 150, no. 2, pp. 498-505, 1982. 

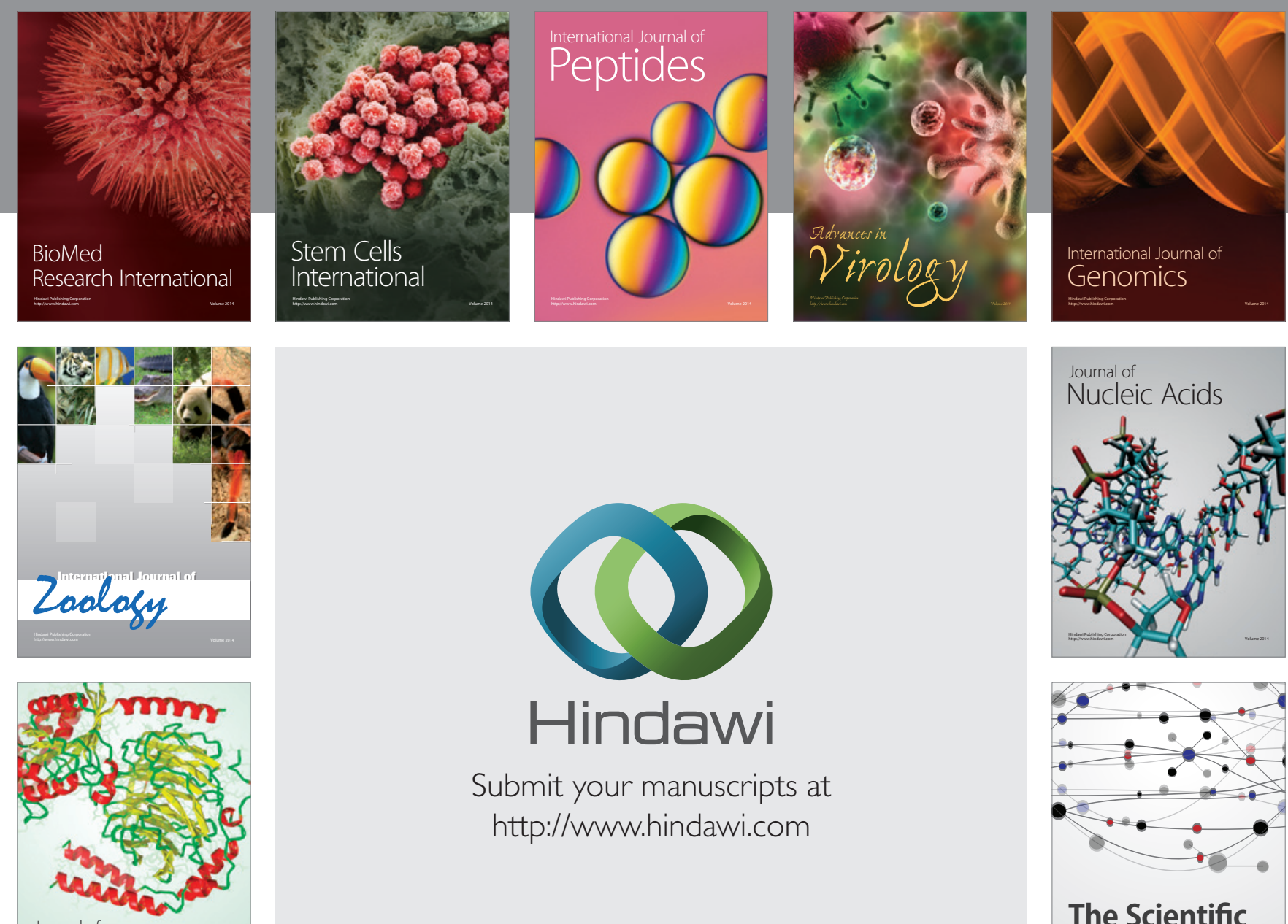

Submit your manuscripts at

http://www.hindawi.com

Journal of
Signal Transduction
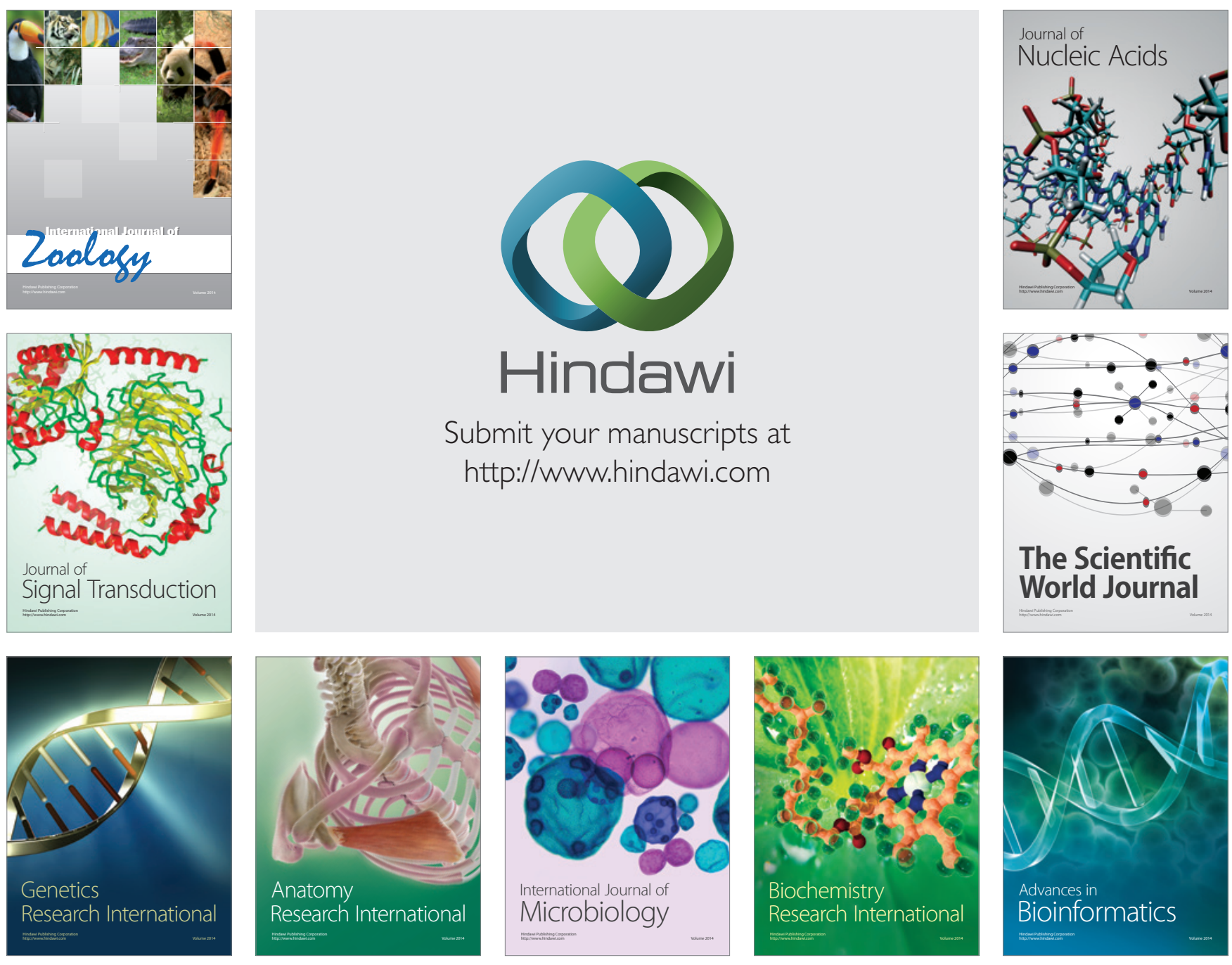

The Scientific World Journal
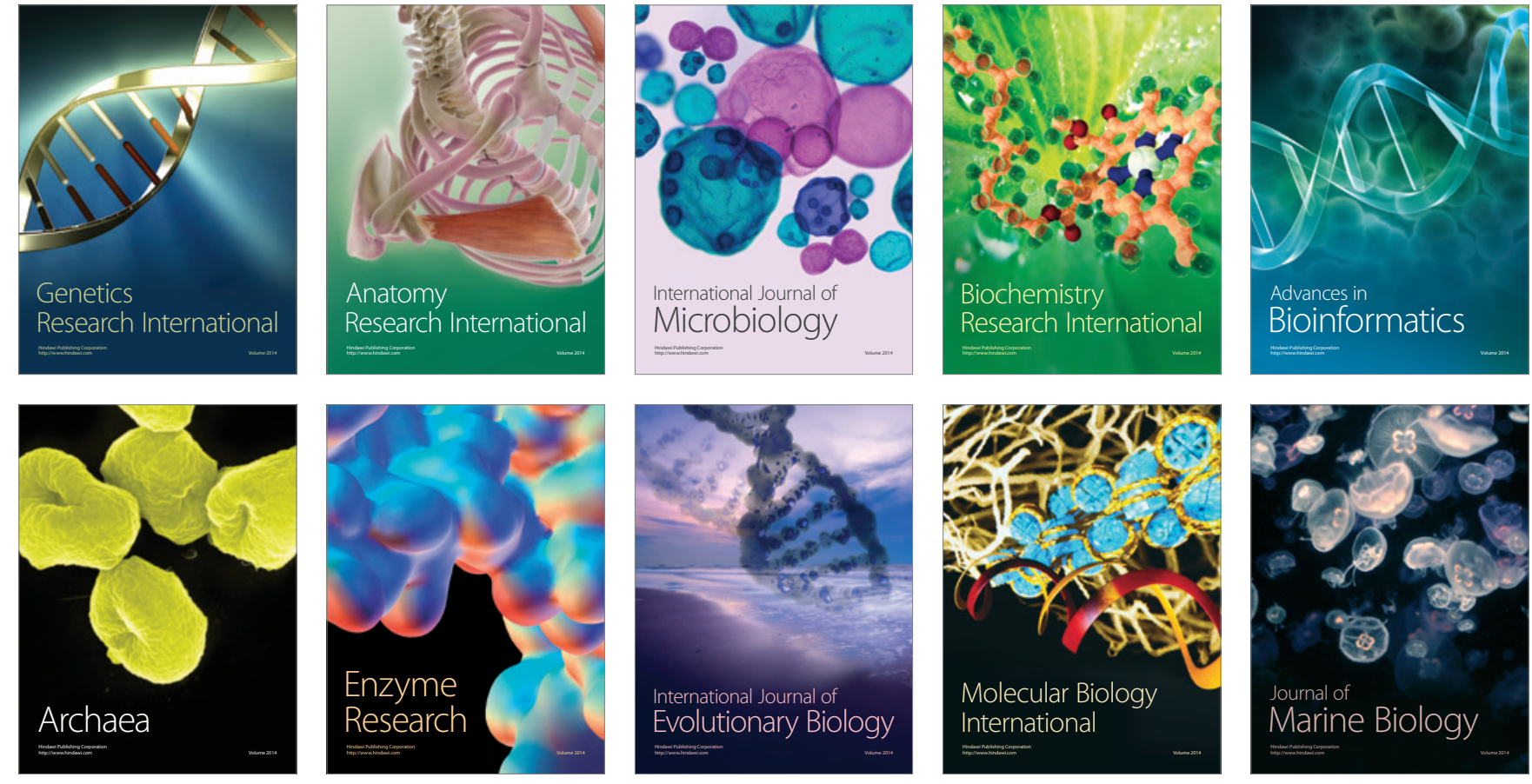